Forestry and Grassland Received on: 09/10/2020 Accepted on: 10/03/2021

\title{
In vitro degradation dynamics of neutral detergent fiber and silage quality of waste from production of heart of palm of peach palm
}

Dinâmica de degradação in vitro da fibra de detergente neutro e qualidade da silagem do resíduo da produção de palmito pupunha

${ }^{1}$ FREITAS, Samuel Galvão de

https://orcid.org/0000-0002-2443-0035

${ }^{2 *}$ BAYÃO, Geraldo Fábio Viana

https://orcid.org/0000-0002-4610-8709

${ }^{3}$ QUEIROZ, Augusto César de

https://orcid.org/0000-0003-2943-0242
${ }^{4}$ PIMENTEL, Robérson Machado

https://orcid.org/0000-0003-3163-5204

${ }^{3}$ ROCHA Junior, Carlos Magno

https://orcid.org/0000-0002-9043-6152

${ }^{5}$ SOUSA, Katiene Régia Silva

https://orcid.org/0000-0002-9945-2706

${ }^{1}$ Universidade Federal de Viçosa - UFV- Departamento de Veterinária, Viçosa/MG, Brasil

${ }^{2}$ Instituto Federal de Educação, Ciência e Tecnologia do Maranhão - IFMA - Campus Maracanã - Departamento de Zootecnia, Av. dos Curiós, s/n - Vila Esperança, São Luís/MA 65095-460, Brasil

${ }^{3}$ Universidade Federal de Viçosa - UFV- Departamento de Zootecnia, Viçosa, MG, Brasil, Viçosa/MG, Brasil

${ }^{4}$ Universidade Federal Fluminense - UFF - Faculdade de Medicina Veterinária, Niterói/RJ, Brasil ${ }^{5}$ Universidade Federal do Maranhão - UFMA- Departamento de Oceanografia e Limnologia, São Luís/MA, Brasil

\section{ABSTRACT}

The objective of the present work was to evaluate the chemical composition, fermentation profile, and degradation parameters of the neutral detergent fiber of three silages made with the waste from production of heart of peach of palm, which consisted of leaf, leaf sheath, and their compound (55\% leaf and $45 \%$ leaf sheath). The waste was packed in experimental silos and open after sixty days of fermentation; silage samples were collected for determination of chemical composition and degradation parameters of neutral detergent fiber at $0,3,6,9,12,24,36,48,72$, and $96 \mathrm{~h}$ of incubation in vitro. A difference was detected in the dry matter, crude protein, neutral detergent fiber, acid detergent fiber, and lignin contents between the three types of silage. The leaf silage showed a higher fractional degradation rate and a higher potentially digestible fraction of neutral detergent fiber over the $96 \mathrm{~h}$ of incubation. As for the fermentative parameters, silage made with the leaf showed a higher $\mathrm{pH}(3,79)$ and lactic acid $(1,18 \%)$, acetic acid $(0,39 \%)$ and propionic acid $(0,24 \%)$. The butyric acid was higher for compound silage $(0,012 \%)$ and ammoniacal nitrogen was higher for sheath silage $(0,94 \%)$. The leaf silage displayed better chemical characteristics, fermentation parameters and in vitro 
degradability properties, proving to be the silage with best nutritional value for feeding ruminants.

Keywords: alternative food, Bactris gasipaes, fermentation, forage conservation, ruminants.

\section{RESUMO}

O objetivo do presente trabalho foi avaliar a composição química, o perfil fermentativo e os parâmetros da degradação da fibra em detergente neutro de três silagens do resíduo da produção do palmito pupunha, sendo estas silagens de folha, bainha foliar e composta (55\% de folha e $45 \%$ de bainha foliar). O resíduo foi acondicionado em silos experimentais e aberto após sessenta dias de fermentação com retirada de amostras das silagens para a determinação da composição química e dos parâmetros de degradação da fibra em detergente neutro nos tempos de $0,3,6,9,12,24,36,48,72$ e 96 horas de incubação in vitro. Houve diferença no teor de matéria seca entre os três tipos de silagem, assim como para a proteína bruta, fibra em detergente neutro, fibra em detergente ácido e lignina. A silagem de folhas apresentou maior taxa de degradação fracional e maior fração potencialmente degradável da fibra em detergente neutro ao longo das 96 horas de incubação. Quanto aos parâmetros fermentativos, a silagem feita com a folha apresentou maiores valores de $\mathrm{pH}(3,79)$ e ácido lático $(1,18 \%)$, ácido acético $(0,39 \%)$ e ácido propiônico $(0,24 \%)$. O ácido butírico foi maior para a silagem composta $(0,012 \%)$ e o nitrogênio amoniacal foi maior para a silagem de bainha $(0,94 \%)$. A silagem de folha apresentou melhores características químicas, parâmetros fermentativos e características de degradabilidade in vitro, demostrando ser a silagem com melhor valor nutricional para alimentação de animais ruminantes.

Palavras - chave: alimento alternativo, Bactris gasipaes, fermentação, conservação de forragem, ruminantes.

\section{INTRODUCTION}

The heart of palm is obtained by extraction by cutting the stem of the palm, such as Euterpe edulis, Euterpe precatoria ou Prestoea acuminate (Vallejo et al., 2014), as well as Bactris gasipaes.

To exploit the heart of palm the palm tree must be cut down for the extraction of the material, which has caused a dramatic reduction in the number of native palms and which has fostered the exploitation of other early-developing and highly productive species such as the Alexander palm (Archontophoenix alexandrae) and the peach palm (Bactris gasipaes).

The peach palm is a domesticated species originating from the Amazon region that was genetically improved lose its spines and become more productive (Silva et al., 2013), featuring characteristics such as early development, tillering, and production of heart of palm of good quality (Botelho et al., 2010), which has stimulated its production in tropical countries. To obtain the heart of palm, the leaves, the sheaths surrounding it, and part of the stems are generated as wastes. These wastes of lignocellulosic nature do not have any commercial value, representing 
an environmental problem due to their accumulation in the environment.

The use of wastes derived from production of heart of palm in the feeding of ruminants is an alternative to minimize the negative environmental impact of its discard. These wastes also represent an economic advantage when utilized in the diet of these animals, which have symbiotic microorganisms that can use fibrous feeds and be converted into products that can be used by men (Bayão et al., 2014).

Based on our assumption that the waste of the heart of peach palm has attributes that can be supplied to ruminant animals such as silage, the objective of this study was to evaluate the chemical composition of silage of peach palm waste (leaf, sheath, and their compound), as well as the fermentation characteristics and in vitro degradability parameters of neutral detergent fiber.

\section{MATERIALS AND METHODS}

The agro-industrial waste utilized was derived from the production of heart palm of peach palm, provided by an agroindustrial producer from Descoberto MG, Brazil. The research was conducted in Viçosa, Minas Gerais.

Three types of silage of waste from the production of heart of peach palm were used: silage of leaf, silage of leaf sheath, and silage of the compound of these two materials. The compound was formulated proportionally to the amount of leaves and leaf sheaths present in the peach palm plant (55\% leaf and $45 \%$ leaf sheath).

The wastes were subjected to wilting for eight hours in the shade to remove excess moisture and subsequently disintegrated in a knife mill with to particles of 2 to $3 \mathrm{~cm}$ and packed into 30 experimental polyvinyl chloride $(\mathrm{PVC})$ silos $(5 \mathrm{~cm}$ diameter $\times 50$ $\mathrm{cm}$ length) with Bunsen valves to allow the escape of fermentation gases. The forage was compressed manually to reach the density of $0.6 \mathrm{~kg} \mathrm{dm}^{-3}$, and then the silos were closed and sealed with adhesive tape, weighed, and stored for 40 days. Samples of waste were collected to analyze its chemical composition before ensilage (Table 1).

Table 1. Chemical composition of waste from production of heart of palm of peach palm fresh.

\begin{tabular}{lccc}
\hline Variable & Leaf & Leaf Sheath & Compound \\
\hline Dry matter Organic matter $^{1}$ & 32.61 & 15.08 & 24.37 \\
Crude protein $^{1}$ & 94.98 & 95.99 & 95.95 \\
Neutral detergente fiber (ap) $^{1}$ & 14.77 & 4.94 & 12.41 \\
Acid detergente fiber (ap) $^{1}$ & 55.21 & 72.53 & 61.72 \\
Non-fiber carbohydrates $^{1.2}$ & 37.14 & 45.31 & 43.21 \\
Lignin $^{1}$ & 24.05 & 18.21 & 20.88 \\
Ether extract $^{1}$ & 6.02 & 14.02 & 10.42 \\
Neutral detergent insoluble protein $^{3}$ & 0.95 & 0.31 & 0.94 \\
Acid detergent insoluble protein $^{3}$ & 22.99 & 29.88 & 24.81 \\
\hline
\end{tabular}

${ }^{1} \mathrm{~g} \mathrm{~kg}-1$ of the dry matter. ${ }^{2} \mathrm{NFC}=\mathrm{OM}-(\mathrm{EE}+\mathrm{NDFap}+\mathrm{CP}) .{ }^{3} \mathrm{~g} \mathrm{~kg}-1 \mathrm{CP}$. ap $=$ corrected for ash and protein.

After the storage period, silos were weighed and opened. The silage was removed and homogenized and opened and the deteriorated parts have been 
discarded, and samples were collected for analyses. Fresh waste and silage samples were dried in a forced-air oven $\left(65^{\circ} \mathrm{C} / 72\right.$ h) and ground in a Willey mill (Thomas Scientific, Swedesboro, NJ) with a $1 \mathrm{~mm}$ screen and stored in plastic containers for determination of dry matter (DM) (Method 934.01; AOAC, 1990), organic matter (OM) (method 942.05; AOAC, 1990), crude protein (CP) (method 920.87; AOAC, 1990), lignin (method 973.18; AOAC, 1990), and ether extract (EE) (Ankom ${ }^{\circledR}$ method; AOCS 2004). Nonfibre carbohydrates (NFC) were calculated as proposed by Detmann \& Valadares Filho (2010). For the neutral detergent insoluble fiber corrected for ash and proteins (NDFap - INCT-CA F-002/1) and acid detergente fiber insoluble corrected for ash and proteins (ADFap - INCT-CA F-004/1). For neutral detergent insoluble protein and acid detergent insoluble protein were performed according to the method INCT-CA N-004/1 and INCT-CA $\mathrm{N}-005 / 1$ respectively.

To estimate the $\mathrm{pH}$ and ammoniacal nitrogen, a sample of silage (25 g) was ground with $200 \mathrm{~mL}$ of water and filtered through a strainer to separate the aqueous and solid medium, and the $\mathrm{pH}$ of the aqueous medium was immediately read. Subsequently, the ammoniacal nitrogen analysis was performed.

For the estimation of fermentation acids (lactate, acetate, propionate, and butyrate), $10 \mathrm{~g}$ of silage sample were diluted in $90 \mathrm{~mL}$ distilled water, homogenized in an industrial blender for $1 \mathrm{~min}$, and filtered through a fine strainer. One milliliter of a $20 \%$ metaphosphoric acid solution was added to $2 \mathrm{~mL}$ of this filtrate, which was then centrifuged; later, the volatile fatty acids were determined by high-performance liquid chromatography.

To determine the in vitro degradability, $350 \mathrm{mg}$ of DM of silages of the waste from production of heart of peach palm, consisting of leaf, sheath, and their compound, and also silages of sugarcane and corn were added to "penicillin" glass bottles with a total volume of $50 \mathrm{~mL}$. Each bottle containing the forage received $28 \mathrm{~mL}$ of McDougall's (McDougall, 1949) buffer solution and were kept in an air-conditioned room (39 ${ }^{\circ} \mathrm{C}$ ) for hydrating the samples.

During the hydration period, rumen fluid was collected from a male cattle with a rumen cannula, with an average weight of $450 \mathrm{~kg}$ and approximate age of 27 months, fed (ad libitum) elephant grass (Pennisetum purpureum) silage and concentrate composed of corn, soybean, and a mineral compound, plus water available at all times. The rumen fluid was collected from the liquid:solid interface region of the rumen, filtered through gauze, stored in a thermos, and taken immediately to the laboratory for the in vitro digestibility assay.

Seven milliliters of a rumen inoculum were added to each bottle, which were sealed immediately after saturation with carbon dioxide. Bottles were maintained at $39^{\circ} \mathrm{C}$ and under orbital agitation at 40 rpm. Fermentation gases were removed using needles, at every three hours.

The evaluated times were $0,3,6,9,12$, $24,36,48,72$, and $96 \mathrm{~h}$ of incubation. At the end of each incubation time, the $\mathrm{pH}$ was determined and the content was filtered in filter crucibles. After filtration, crucibles were placed in autoclavable polyethylene bottles (120 $\mathrm{mL}$ ), $50 \mathrm{~mL}$ neutral detergent fiber were added, and the solution was autoclaved $\left(105^{\circ} \mathrm{C} / 1 \mathrm{~h}\right)$ for extraction of the neutral detergent soluble components by the micro-extraction method (Pell \& Schofield, 1993). Later, the solution was subjected to vacuum filtration and the 
residue was washed with running water and acetone. The residual NDF was obtained after drying the material in an oven $\left(105^{\circ} \mathrm{C} / 16 \mathrm{~h}\right)$.

Adopting Gauss-Newton's algorithm, the NDF residues at the different times for each treatment were subjected to the adjustment of the non-linear logistic model (Van Milgen et al., 1991):

$R t=\beta \times(1+\lambda \times t) x \exp (-\lambda \times t)+I$, where: $\mathrm{Rt}=\mathrm{NDF}$ undegraded residue at time $(\%) ; \beta=$ NDF potentially degradable fraction (NDFap) $(\%) ; \lambda=$ combined lag and degradation fractional rate $\left(\mathrm{h}^{-1}\right) ; \mathrm{t}=$ time $(\mathrm{h})$; and $\mathrm{I}=\mathrm{NDF}$ undegradable fraction (\%).

For this case, because parameter $\lambda$ represented the lag and degradation rates combined, the fractional degradation rate was estimated from $\lambda$ by using the properties of gamma- 2 distribution: $\mathrm{Kd}=$ $0.59635 \lambda$, where $\mathrm{Kd}=$ NDFap fractional degradation rate $\left(\mathrm{h}^{-1}\right)$.

For the silages, the experimental design was completely randomized, with 10 replicates for each one of the treatments, totaling 30 silos. The experimental model was:

$$
\mathrm{Yij}=\mu+\tau \mathrm{i}+\varepsilon \mathrm{ij}
$$

where Yij experimental response of treatment $\mathrm{i}$ at replicate $\mathrm{j} ; \mu=$ overall constant; $\tau \mathrm{i}=$ effect of treatment $\mathrm{i}$ (wastes); and $\varepsilon \mathrm{ij}=$ experimental error. Data were analyzed on SAS statistical software and means were compared by Tukey's test at 5\% significance level.

\section{RESULTS}

Dry matter contents of the fresh leaf, sheath, and compound were $32.6 \%$, $15.1 \%$, and $24.4 \%$ (Table 1 ), whereas the DM contents for the silages of these same materials were $27.6 \%, 14.0 \%$, and $21.1 \%$, respectively (Table 2 ).

The leaf silage had the highest $\mathrm{CP}$ content $(\mathrm{P}<0.05)$, followed by the compound and sheath silages (Table 2). The NDFap and lignin contents, in turn, were higher $(\mathrm{P}<0.05)$ in the sheath silage (Table 2). The non-fiber carbohydrate (NFC) contents of the silage were higher $(\mathrm{P}<0.05)$ in the leaf silage (Table 2), while NDIP and ADIP contents were higher in the sheath silage (Table 2).

Table 2. Chemical composition of silage from production of heart of palm of peach palm.

\begin{tabular}{lcccc}
\hline Variable & Leaf & Leaf Sheath & Compound & $\begin{array}{c}\text { CV } \\
(\%)\end{array}$ \\
\hline Dry matter & $27.6^{\mathrm{a}}$ & $14.0^{\mathrm{c}}$ & $21.1^{\mathrm{b}}$ & 24.0 \\
Organic matter $^{1}$ & $95.1^{\mathrm{c}}$ & $95.9^{\mathrm{a}}$ & $95.7^{\mathrm{b}}$ & 0.2 \\
Crude protein $^{1}$ & $13.9^{\mathrm{a}}$ & $4.3^{\mathrm{c}}$ & $10.2^{\mathrm{b}}$ & 43.6 \\
Neutral detergente fiber (ap) $^{1}$ & $52.3^{\mathrm{c}}$ & $68.1^{\mathrm{a}}$ & $59.6^{\mathrm{b}}$ & 13.3 \\
Acid detergente fiber (ap) $^{1}$ & $34.1^{\mathrm{c}}$ & $49.5^{\mathrm{a}}$ & $41.3^{\mathrm{b}}$ & 15.4 \\
Non-fiber carbohydrates $^{1.2}$ & $28.1^{\mathrm{a}}$ & $23.4^{\mathrm{c}}$ & $25.1^{\mathrm{b}}$ & 10.4 \\
Lignin $^{1}$ & $6.1^{\mathrm{c}}$ & $13.8^{\mathrm{a}}$ & $9.7^{\mathrm{b}}$ & 25.5 \\
Ether extract $^{1}$ & $0.8^{\mathrm{b}}$ & $0.2^{\mathrm{c}}$ & $0.8^{\mathrm{a}}$ & 48.2 \\
Neutral detergent insoluble protein $^{3}$ & $22.5^{\mathrm{c}}$ & $29.4^{\mathrm{a}}$ & $24.4^{\mathrm{b}}$ & 20.7 \\
Acid detergent insoluble protein $^{3}$ & $15.3^{\mathrm{c}}$ & $18.7^{\mathrm{a}}$ & $16.3^{\mathrm{b}}$ & 22.8 \\
\hline
\end{tabular}

Means followed by different letters in the same line, are significantly different $(\mathrm{P}<0.05)$ by Tukey test. ${ }^{1} \mathrm{~g} \mathrm{~kg}^{-1} \mathrm{of} \mathrm{the}$ dry matter. ${ }^{2} \mathrm{NFC}=\mathrm{OM}-(\mathrm{EE}+\mathrm{NDFap}+\mathrm{CP}) .{ }^{3} \mathrm{~g} \mathrm{~kg}^{-1} \mathrm{CP}$. ap $=$ corrected for ash and protein. $\mathrm{CV}=$ coefficient of variation 
The silage made with the leaf waste showed the highest $\mathrm{pH}$ value $(\mathrm{P}<0.05)$, which was 3.79 , followed by the compound and sheath silages, with 3.66 and 3.37, respectively (Table 3).

Table 3. Qualitative characteristics of silage from production of heart of palm of peach palm.

\begin{tabular}{lcccc}
\hline Variable & \multicolumn{3}{c}{ Waste } & \\
\cline { 2 - 4 } & Leaf & Sheath & Compound & CV (\%) \\
\hline $\mathrm{pH}$ & $3.79^{\mathrm{a}}$ & $3.37^{\mathrm{c}}$ & $3.66^{\mathrm{b}}$ & 5.13 \\
Ammonia $\left(\mathrm{NH}_{3}\right)^{1}$ & $0.29^{\mathrm{c}}$ & $0.94^{\mathrm{a}}$ & $0.43^{\mathrm{b}}$ & 37.56 \\
Lactic acid $^{\mathrm{a}}$ & $1.18^{\mathrm{a}}$ & $0.33^{\mathrm{c}}$ & $0.73^{\mathrm{b}}$ & 54.24 \\
Acetic acid $^{2}$ & $0.39^{\mathrm{a}}$ & $0.24^{\mathrm{c}}$ & $0.35^{\mathrm{b}}$ & 31.71 \\
Propionic acid & $0.24^{\mathrm{a}}$ & $0.04^{\mathrm{c}}$ & $0.14^{\mathrm{b}}$ & 67.49 \\
Butyric acid $^{2}$ & $0.009^{\mathrm{b}}$ & $0.007^{\mathrm{b}}$ & $0.012^{\mathrm{a}}$ & 46.95 \\
\hline
\end{tabular}

Means followed by different letters in the same line, are significantly different $(\mathrm{P}<0.05)$ by Tukey test. ${ }^{1 \%}$ do total nitrogen. ${ }^{2} \%$ of dry matter

Ammoniacal nitrogen estimates were higher $(\mathrm{P}<0.05)$ in the sheath silage as compared with the others (Table 3 ).

Lactic acid concentration was higher $(\mathrm{P}<0.05)$ in the leaf silage, whereas butyric acid was present in a larger amount $(\mathrm{P}<0.05)$ in the sheath silage (Table 3).
The compound silage and the sheath silage showed the lowest potentially degradable fractions $(\beta)$ among the treatments (Table 4), and also the highest undegradable fractions (I) and the lowest fractional degradation rates $(\mathrm{Kd})$.

Table 4. Estimates of degradation dynamics parameters of neutral detergent fiber and their respective standard deviations for the evaluated silages.

\begin{tabular}{|c|c|c|c|c|c|}
\hline Variable & Leaf & Leaf Sheath & Compound & Sugar cane & Corn \\
\hline$\beta$ & $39.47 \pm 0.600$ & $36.79 \pm 1.200$ & $29.20 \pm 0.900$ & $37.29 \pm 0.9$ & $51.28 \pm 0.8$ \\
\hline I & $60.53 \pm 0.500$ & $63.21 \pm 0.900$ & $70.80 \pm 0.700$ & $62.71 \pm 0.9$ & $48.72 \pm 0.7$ \\
\hline$\lambda$ & $0.103 \pm 0.018$ & $0.099 \pm 0.004$ & $0.080 \pm 0.003$ & $0.109 \pm 0.004$ & $0.114 \pm 0.008$ \\
\hline $\mathrm{Kd}$ & 0.061 & 0.059 & 0.048 & 0.065 & 0.068 \\
\hline
\end{tabular}

\section{DISCUSSION}

Fresh sheath and fresh compound showed DM contents of $15.1 \%$ and $24.4 \%$, respectively (Table 1 ), which are below the minimum recommended for silage which is 32 to $35 \%$ (Windle et al., 2014) for the moment of ensilage. Values below $25 \%$ may compromise the silage quality due to the development of undesirable microorganisms and higher effluent losses, with consequent higher DM losses. Although the DM of the fresh leaf waste was within the recommended (Table 1), the leaf silage had 27.6\% DM (Table 2). This reduction was also observed by other authors (Oliveira et al., 2010; Schmidt et al., 2010), in experiments with silage of hearth of 
peach palm waste, caused by leaching and/or gases.

The higher CP content of the leaf and compound silages compared with the sheath silage (Table 2) is related to the higher CP content of the fresh leaf waste (Table 1). Crude protein values below de $7-8 \%$ are considered low and may compromise the animal performance because this percentage is insufficient for the use of the fibrous components by the rumen microbiota (Lazzarini et al., 2009). Thus, aiming to improve the protein content in the sheath silage, the addition of protein additives should be considered during the preparation of silages that include this waste.

Comparing the silages, the sheath may provide a greater rumen fill and a reduction of voluntary intake due to the rumen-fill effect caused by the higher $(\mathrm{P}<0.05)$ NDFap content (Table 2). Coupled with this is the higher lignin content $(\mathrm{P}<0.05)$ of the silage of the sheath waste that contributes to the lower nutritional quality of this silage, since lignin is correlated with unavailability of digestible energy for making the energy content of forages inaccessible (Frei, 2013).

The NDFap contents of the silage (Table 2) compared with the fresh waste (Table 1) showed a decline, which may be related to losses mainly regarding the solubilization of the hemicellulose fraction. A similar response was observed by Schmidt et al. (2010) in control silage of peach palm sheath and this silage enriched with urea and Bayão et al. (2017) in silage of palm waste produced from Alexander Palm.

In contrast, comparing the NFC contents of the silages (Table 2) with the fresh materials (Table 1), this nutrient was found to increase in the silages. The NFC contents of the silages were expected to decrease, as it is composed of watersoluble sugars (mono and disaccharides), starch, and pectin (Cañizares et al., 2009), which are neutral-detergent soluble. In fact, this percentage variation in the contents is a dilution effect, because, in the whole, comprising fiber carbohydrates (cellulose, hemicellulose, and lignin $=\mathrm{NDF}$ ) and non-fiber carbohydrates, when the concentrations of fiber carbohydrates are decreased in percentage, the non-fiber carbohydrates content is increased. Thus, a reduction of the NDF content increases the NFC content in percentage.

Compared with the silage (Table 2), the lignin content of the fresh waste (Table 1) did not show great divergences, which is expected, since the lignin content does not change during the silage-production fermentation processes.

Concentrations of NDIP and ADIP in the fresh waste (Table 1) and in the silage (Table 2) practically did not change. This is a desirable result, indicating that fermentation did not make the proteins unavailable to the rumen microorganisms.

The $\mathrm{pH}$ value of silages (Table 3) are a little lower than the $\mathrm{pH}$ range between 3.8 and 4.2 (21) recommended to improve fermentation and to prevent the development of undesirable microorganisms that might compromise the silage quality.

The sheath silage had the highest $(\mathrm{P}<0.05)$ estimate for ammoniacal nitrogen content among the silages (Table 3), probably because of the greater development of microorganisms that cause proteolysis due to the lower dry matter content of the waste prior to ensilage (Table 1). Ammoniacal nitrogen values greater than $10 \%$ indicate 
considerable protein degradation during the fermentation processes (Machado et al., 2012), since activity of bacteria of the genus Clostridium can promote the deamination of amino acids ( $\mathrm{Lu}$ Zhang et al., 2019), which was not observed in the present experiment.

The higher lactic acid content $(\mathrm{P}<0.05)$ of the leaf silage in relation to the volatile fatty acids (acetic, butyric, and propionic) demonstrates the better fermentation profile of this silage (Table 3 ), since lactic acid is primarily responsible for reduces the $\mathrm{pH}$ (Ávila et al., 2014). This lactic acid also contributed to the lower ammoniacal nitrogen values found in the leaf silage, as it stimulates the development of microorganisms beneficial to silage quality.

Butyric acid content $(\mathrm{P}<0.05)$ was higher in the sheath silage among the silages (Table 3). The low DM content displayed by this silage might have been responsible for this concentration, since Clostridium bacteria, which have butyrate as a product of their metabolism, are sensitive to the water availability and require moist conditions to develop (Silva et al., 2011).

Among the silages, those made of compound and sheath showed the lowest potentially degradable fractions $(\beta)$ (Table 4) and also the highest undegradable fractions (I) and the lowest fractional degradation rates $(\mathrm{Kd})$. The lignin content observed in the compound and sheath silages (Table 2) influenced the higher undegradable fraction (I), relating it negatively to the degradability of the waste by the rumen microbiota, since the lignin content may be considered to be involved in the reduction of forage digestibility (Silva et al., 2015). The variation in digestibility provides considerable differences between the evaluated feedstuffs, especially regarding the energy availability, because fraction $\mathrm{I}$ is related to the rumen-fill effect and, in turn, decreasing as increases the potentially degradable fraction (Muniz et al., 2012). The leaf waste silage showed better fermentation parameters in rumen fluid as compared with the other wastes from the production of heart of peach palm and with the sugarcane silage (Table 4). The higher concentration of NFC, which are highly fermentable in the rumen, as well as the lower lignin content (Table 2), led to this condition, which makes silage of the leaf waste an interesting alternative for feeding ruminants.

Despite the lower potentially degradable fraction of the leaf silage compared with the corn silage (Table 4), the lower costs of producing silage with leaf from production of heart of peach palm compared with the costs of the corn silage should be taken into account, since the peach palm leaf has zero or very low cost for being a waste from the agroindustrial process. Thus, new studies evaluating the animal performance and economic return utilizing the silages produced with the waste generated in heart of palm of peach palm production should be fostered aiming to evaluate the economic and environmental benefits of using this alternative feedstuff.

The silage of leaf derived from production of heart of peach palm has better chemical characteristics, fermentation parameters, and in vitro degradability characteristics, demonstrating int this research to be the silage with best nutritive value for feeding ruminants.

ACKNOWLEDGEMENTS 
At Fundação de Amparo à pesquisa do Estado de Minas Gerais (FAPEMIG) and Fundação de Amparo à Pesquisa e ao Desenvolvimento Cientifico $e$ Tecnológico do Maranhão (FAPEMA) for financial support.

\section{REFERENCES}

ÁVILA, C.L.S.; CARVALHO, B.F.; PINTO, J.C.; DUARTE, W.F.;

SCHWAN, R.F. The use of Lactobacillus species as starter cultures for enhancing the quality of sugar cane silage. Journal of Dairy Science, v.97, n.2, p.940-951, 2014.

BAYÃO, G.F.V.; MARCONDES, M.I.; QUEIROZ, A.C.; PIMENTEL, R.M.; CARDOSO, L.L.; CARDOSO, A.J.S.; SOUSA, K.R.S.; BATALHA, C.D.A. 2017. Chemical composition and fermentative parameters of heart of palm waste produced from Alexander Palm ensiled with chemical additives.

Revista Brasileira de Zootecnia, v.46, n.6, p. 489-493, 2017.

BAYÃO, G.F.V.; QUEIROZ, A.C.; FREITAS, S. G.; BATALHA, C.D.A.; SOUSA, K.R.S.; PIMENTEL, R.M.; CARDOSO, L.L.; CARDOSO, A.J.S. Replacement the waste from heart of palm from Alexander Palm (Archontophoenix alexandrae) on sugarcane silage in sheep diets.

Archivos Latinoamericanos de Nutrición, v.64, n.4, p.271-276, 2014.

BOTELHO, M.C.; LEME, S.C.; LIMA, L.C.O.; ABRAHÃO, S.A.;

SILQUEIRA, H.H.; HITARRA, A.B. Quality of fresh cut pupunha palm cabbage: application of antioxidants.
Ciência e agrotecnologia, v.34, n.5, p.1312-1319, 2010.

CAÑIZARES, G.I.L.; RODRIGUES, L.; CAÑIZARES, M.C. Metabolism of non-structural carbohydrates in ruminants. Archives of Veterinary

Science, v.14, n.1, p.63-73, 2009. DETMANN E., VALADARES FILHO SC. On the estimation of non-fibrous carbohydrates in feeds and diets. Arquivo Brasileiro de Medicina Veterinária e Zootecnia, v.62, n.4, p.980-984, 2010.

Frei, M. Lignin: Characterization of a multifaceted crop component. The Scientific World Journal, v.2013, p.125, 2013.

LAZZARINI I.; DETMANN E.; SAMPAIO, C.B.; PAULINO, M.F.; VALADARES FILHO, S.C.; SOUZA, M.A.; OLIVEIRA, F.A. Intake and digestibility in cattle fed low-quality tropical forage and supplemented with nitrogenous compounds. Revista Brasileira de Zootecnia, v.38, n.10, p. 2021-2030, 2009.

ZHANG, L.; ZHOU, X.; GU, Q.; LIANG, M.; MU, S.; ZHOU, B.; HUANG, F.; LIN, B.; ZOU, C. Analysis of the correlation between bacteria and fungi in sugarcane tops silage prior to and after aerobic exposure. Bioresource Technology, v.291, p.1-8, 2019.

MACHADO, F.S.; RODRIGUEZ, N.M.; RODRIGUES, J.A.S.; RIBAS, M.N.; TEIXEIRA, A.M.; RIBEIRO JÚNIOR, G.O.; VELASCO, F.O.; GONÇALVES, L.C.; GUIMARÃES JÚNIOR, R.; PEREIRA, 
L.G.RQualidade da silagem de híbridos de sorgo em diferentes estádios de maturação. Arquivos Brasileiros de Medicina Veterinária e Zootecnia, v.64, n.3, p.711-720, 2012.

MCDOUGALL, E.I. Studies on ruminal saliva. 1. The composition and output of sheep's saliva. Biochemistry Journal, v.43, n.1, p.99-109,1948.

MUNIZ, E.B.; MIZIBUTI, I.Y.; PEREIRA, E.S.; PIMENTEL, P.G.; RIBEIRO, E.L.A.; PINTO, A.P. Ruminal kinetics of the fibrous fraction of ruminant roughages. Revista Ciência Agronômica, v.43, n.3, p.604-610, 2012.

OLIVEIRA, L.S.; PEREIRA, L.G.R.; AZEVEDO, J.A.G.; PEDREIRA, M.S.; LOURES, D.R.S.; BOMFIM, M.A.D. BRITO; R.L.L. Nutritional characterization of co-product silages of pejibaye. Revista Brasileira de Saúde e Produção Animal, v.11, n.2., p.426439, 2010.

PELL, A.N.; SCHOFIELD, P. Computerized monitoring of gas production to measure forage digestion in vitro. Journal of Dairy Science, v.76, n.4, p.1063-1073, 1993.

SILVA, T.C.; DANTAS, P.A.S.; DÓREA, J.R.R., SANTOS, E.M.; ZANINE, A.M.; PEREIRA, G. Microbial populations, fermentation profile and chemical composition of elephant grass silages with jackfruit. Archivos de Zootecnia, v.60, n.230, p.247-255, 2011.

SCHMIDT, P.; JUNIOR, P.R.; TOLEDO, L.M; NUSSIO, L.G.;
ALBUQUERQUE, D.S.; MEDURI, B. Fermentative losses and chemical composition of pupunha palm byproducts ensiled with chemical additives. Revista brasileira de Zootecnia, v.39, n.2, p.262-267, 2010.

SILVA, L.M.M.; SOUZA, F.C.; CASTRO, D.S.; NUNES, J.S.; ALMEIDA, F.A.C. Evaluation of Physical and Physicochemical the Pupunha. Revista verde de agroecologia e desenvolvimento sustentável, v.8, n.3, p.05-08, 2013.

SILVA, M.D.A., CARNEIRO, M.S.S; PINTO, A.P.; POMPEU, R.C.F.F.; SILVA, D.S.; COUTINHO, M.J.F.; FONTENELE, R.M. Evaluation of the chemical composition of woody forage silages of the Brazilian semiarid.

Semina: Ciências Agrárias, v.36 p., n. 1, p.571-578, 2015.

VALLEJO, M.I.; GALEANO, G.; BERNAL, R. ZUIDEMA, P.A. The fate of populations of Euterpe oleracea harvested for palm heart in Colombia. Forest Ecology and Management, v.318, v. 2014, p.274-284, 2014.

VAN MILGEN, J.; MURPHY, L.L.; BERGER, L.L. A compartmental model to analyze ruminal digestion. Journal of Dairy Science, v.74, p. 2515-2529, 1991.

Windle, M.C.; Walker, N.; Kung Jr, L. Effects of an exogenous protease on the fermentation and nutritive value of corn silage harvested at different dry matter contents and ensiled for various lengths of time. Journal of Dairy Science, v.97, n.5, p.3053-3060,2014. 